I. G. Sakhno, Dr. Sc. (Tech.), Assist. Prof., orcid.org/0000-0002-8592-0572, S.V.Sakhno, orcid.org/0000-0003-3917-9143
State Higher Educational Institution "Donetsk National Technical University”, Pokrovsk, Ukraine, e-mail: ivan. sakhno@donntu.edu.ua

\title{
RESEARCH ON A NEW METHOD FOR NON-ADHESIVE FIXING OF ROCKBOLTS
}

Purpose. Theoretical and experimental evaluation the mechanism of work, bearing capacity and pre-destructive deformations of the anchor system with a new nonadhesive fixing of bolts.

Methodology. The research is conducted through the analytical method, using the base law of classical elasticity theory, and the method of physical modeling. Laboratory tests on the axial load of bolts are made on a real scale on specimens of concrete filled in metal pipes. Three series of models were tested: two series with fixing bolts with selfexpanding mixtures, and one series with adhesive fixing. The results are presented as "stress-strain" graphs.

Findings. The range of fluctuation of bearing capacity of "bolt-expanding mixture-rock" system with the change in the main factors is analyzed analytically. The rated bearing capacity of the mentioned system is not less than that of the known energy-absorbing bolts. The mechanism of anchors attached to self-expandable mixtures is determined experimentally. The "load-deformation" curve has rigid and flexible zones, which is characteristic of energy-absorbing bolts. The maximum force of fixing anchors with expanding blends exceeds the effort for bolts fixed by resins more than twice, and the forces in the flexible mode are $67 \%$ larger than the maximum ones in the experiment with fixing Cement KL (Orica) and $99 \%$ more than the UF-MT-15 resin.

Originality. The mechanism of active frictional fixing of anchor bolts by means of compression by mixtures extending in a solid phase in the process of hydration hardening is revealed. The created anchoring system has a high bearing capacity with large pre-destructive deformations. The efficiency of fixing anchor bolts with self-expanding mixture with hydration with the formation of pressure 30-50 MPa has been proved.

Practical value. The use of research results allows increasing the efficiency of support of roadways by anchoring systems, as well as increasing the stability of rocks at large post elastic deformations.

Keywords: anchor bolt, bearing anchor capacity, deformation, self-extending mixture, energy absorbing bolt, bolting

Introduction. Coal mining at depths of about $1000 \mathrm{~m}$ is characterized by structural change in the rock mass and high stresses and rock failure. The failed rock intends to move towards the open space of the roadway. Large rock deformations are associated with rock squeezing, dilatation [1]. Therefore, there is a need for new methods of engineering response [2]. Existing fixing systems, including metal anchor bolts, fixed with polymeric resins, are not adapted to such conditions $[3,4]$.

Contour deformation of roadways at today's depths of mining of coal deposits often exceed yield of arch

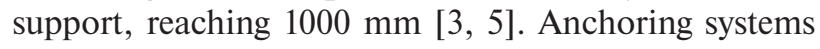
are the most modern type of rock support that is widespread in the world mining practice to secure stability of roadways such as tunnels, galleries, and others. According to the fixing mechanism, all anchor bolts can be divided into 3 groups: anchors with point fixing, as a rule, mechanical, anchors with fixing with resins along the whole length and friction anchors. Anchors of the first group are fixed in a hole at two points - in the bottom part of hole and in the wellhead. The quality of fixing such an anchor and its bearing capacity are determined by the reliability of bolt head fixation.

In modern conditions, such bolts are rarely used due to insufficient bearing capacity (according to Steghern [6] to $160 \mathrm{kN}$ for axial deformations of $55 \mathrm{~mm}$ for bolt

(C) Sakhno I. G., Sakhno S. V., 2018 with a head with a diameter of $20 \mathrm{~mm}$ ) and difficult design. The anchors of the second group are fixed due to adhesion with resin, cement or other binders along the whole length. At the same time, the bearing capacity of reinforcing bolt is used as much as possible. So, according to Stillborough's data for a bolt with a diameter of $20 \mathrm{~mm}$, loading reaches $170 \mathrm{kN}$, and pre-destructive deformations is $20 \mathrm{~mm}$, according to Steghern, these are $210 \mathrm{kN}$ and $40 \mathrm{~mm}$, respectively [6]. Reinforced steel bolts with fixing along the bolt are most common in the world due to their advantages: simplicity, reliability, and installation speed. The disadvantage of this type bolts is small deformation ability and a rigid mode. Laboratory tests [1] show that after deformations of $20-30 \mathrm{~mm}$ on the basis of $150 \mathrm{~mm}$, such bolts are destroyed. This occurs because an anchor bolt fixed by the binders has no possibility to be deformed along its full length, which leads to its local loading and fracturing at crack and formation of layers (Fig. 1).

Friction bolts are fixed by the friction force between the walls of borehole and bolt. They allow for large deformations, but have a small bearing capacity for quasi constant resistance. So according to Stillborough's and Steghern's tests for Split Set bolts, the bearing capacity is about $50 \mathrm{kN}$ for deformations greater than $120 \mathrm{~mm}$. And for anchors of Swellex type, after Steghern's tests, the maximum bearing capacity was $121 \mathrm{kN}$ for deformations of $26 \mathrm{~mm}$, and after shift by $180 \mathrm{~mm}$ it made $63 \mathrm{kN} \mathrm{[6].}$ 


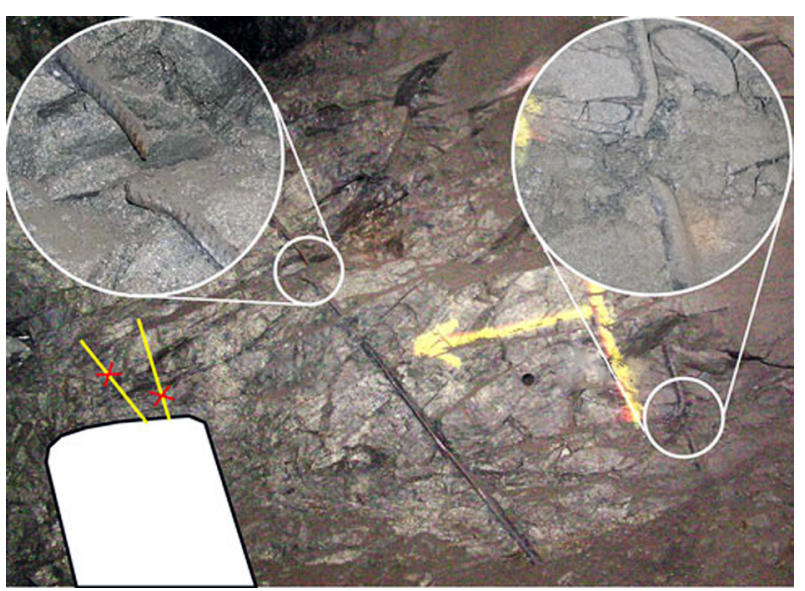

Fig. 1. Destruction of two anchors, fixed along the bolt of roadway roof [1]

Flexible cable bolts and fiberglass bolts should be included into a separate group. Cable bolts fixed along their full length according to Steghern's under the action of axial loading rigidly resist to $170 \mathrm{kN}$ at deformations of $25 \mathrm{~mm}$, after which they begin to slip in a hole up to $250 \mathrm{~mm}$ with increasing load up to $210 \mathrm{kN}$ [6]. The authors of the tests explain this effect by dilatation processes in the hole. Bolts from fiberglass with a diameter of $22 \mathrm{~mm}$ reach a load of $380 \mathrm{kN}$ at deformations of $37 \mathrm{~mm}$, and then they collapse. These bolts are the main competitor of reinforcing steel bolts fixed along the full length with binders, the volume of their implementation in the world is increasing every year. However, the bolts of fiberglass do not allow holding back large deformations without destroying.

Creating an anchoring system, which would have a high bearing capacity at large pre-destructive deformations, is an urgent scientific and practical task. This trend has been observed in the scientific field for over 30 years. During this time, a large number of anchor bolt designs have been developed, but their main drawbacks, which restrain active industrial implementation, are structural complexity, high complexity of installation and low load bearing capacity.

Analysis of the recent research. Among the most important in the outline of developments in recent years there should be Garford Dynamic bolts, Roofex bolts [6], D-Bolts [1, 6], and Yield-Lok bolts [6], He-Bolts [7] and the Mechanical Dynamic Sandwick Bolts (Darlington bolts). In the literature all these anchors refer to energy-absorbing or plastic bolts [1,5-7]. The main conditions of applying these bolts are mine roadways with large deformations and those under the dynamic influence. In essence, these bolts have the same principle of working: tensioning a part of a bolt with a locally modified diameter with high friction or with extrusion through another half of the bolt or a hole wall.

Ukrainian scientists have also worked on the development of bolts with large displacement. The most significant contribution was made by the following scientists. Bondarenko V.I., Kovalevska I.A., Simanovych G. A. and Porotnikov V.V. have developed a tube anchor TA2 for the conditions of weak contouring rocks, which represents the modification of a bolt, which is set by energy of explosion. Kasyan M.M. has patented a yielding anchor that consists of a metal rod with a resin attached the wavy forming end at the bottom of the hole, with the rest of the rod made in the form of a twisted band, the inner surface of which contacts the run-around roller, and the free end of which is directed towards the fixed part and has a locking ring that covers the strip.

An alternative variant of containment of large deformations by bolt fixing is proposed by Nazymko V. V. The essence of the proposed method is that the bolts are not sent to the hole completely, and the section between the embouchure of boreholes and pin nut extending into the cavity makes $0.01-0.5$ of the total length of the bolt. However, despite the diversity of ideas, the development of domestic scientists has not had large scientific resonance and industrial implementation. Therefore, we will concentrate on the analysis of the most well-known energy-absorbing systems.

Laboratory tests on static axial load allowed establishing that Garford bolts withstand $170 \mathrm{kN}$ axial load at $270 \mathrm{~mm}$ deformations [6], Ruffes - 94-108 $\mathrm{kN}$ at 703-840 $\mathrm{mm} \mathrm{[6],} \mathrm{D-bolts}-281 \mathrm{kN}$ at $140 \mathrm{~mm} \mathrm{[6],}$ Yield-Lok $-99-81 \mathrm{kN}$ at $175-230 \mathrm{~mm}$ [6], Ne-Bolts MG-12-2 NPR with a dynamic axial load - $318.76 \mathrm{kN}$ at $702.16 \mathrm{~mm}$ [7], MD Sandvick - bolts $200-250 \mathrm{kN}$ at $300 \mathrm{~mm}$.

Thus, they all have a significant advantage over deformations over classical anchor bolts, while providing a sufficiently high bearing capacity. But constructively, all of these bolts are much more complicated than steel resin bolts or cable bolts, which, accordingly, increases their cost and reduces the efficiency of implementation. In addition, some of the bolts listed require special installation technology.

The prototype of energy-absorbing bolts are Cone bolts [8] (Fig. 2, a). Its construction is extremely simple, although the performance is not so high (axial load is $190 \mathrm{kN}$, deformation makes $120 \mathrm{~mm}$ [8]). The yielding mode of the bolt is ensured by the displacement of its
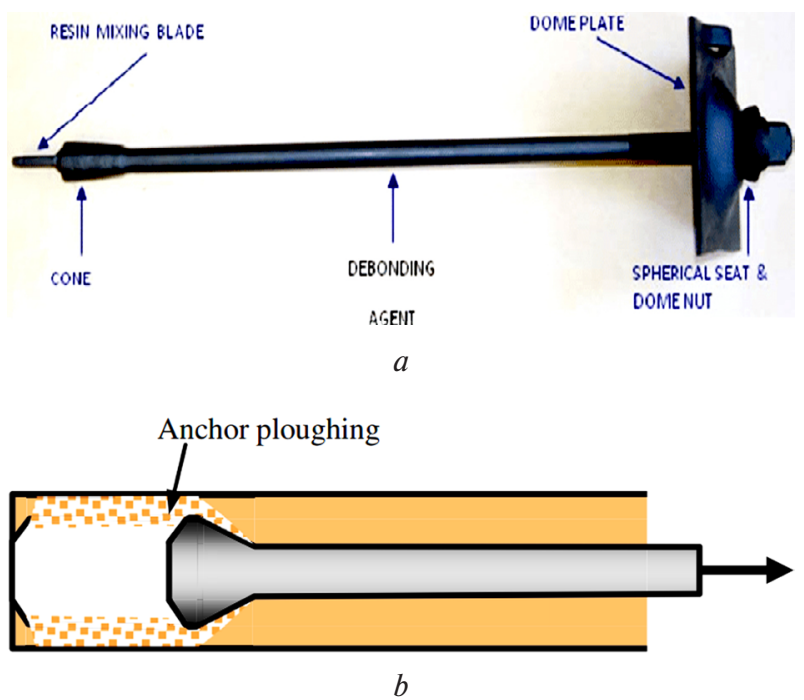

Fig. 2. Modified cone bolt (a) and the mechanism of its operation (b) [6] 
bottom part (in the form of a cone) in the direction of embouchure boreholes with the destruction of hardened resin between the walls of hole and the bolt. The mechanism of work of the bolt is shown in Fig. 2, $b$.

Problem statement. Taking into account the aforementioned development of an anchoring system with a simple construction and low labor-intensiveness of installation with high bearing capacity and large destructive deformations is an important scientific and practical task. Creating such an anchoring system and studying the mechanism of its work is the task of the research presented in the article.

The idea of the developed method for fixing bolts consists in the fact that fixation of a bolt in the hole does not occur due to adhesion, but due to compression along the bolt mixture with self-expansion in the process of hardening [9]. After reaching the initial maximum load, the bolt moves in a hole with a conditionally constant resistance, which is provided by friction between the solidified expanding mixture and the bolt (Fig. 3).

The advantage of this method for fixing bolts over known friction bolts is that expansion pressures, depending on the mix specification, reach 30-50 $\mathrm{MPa}$ [10], which significantly increases the quality of fixing.

In this case, the geometry and material of the bolt may be different: it may be a smooth (no rebar) bolt of constant or variable diameter, a cable, a tube, a bolt of fiberglass, a cone bolt, and others. Filling the mixture into the borehole can be done in any known way: encapsulation, spraying, and so forth.

Moreover, regardless of the location of cracks forming and their number, the mechanism of operation of the bolt near the crack along the length will be the same.

The bearing capacity of the anchoring system will depend on the pressure of expansion of the binder, the coefficient of friction between the bolt and the binder, the coefficient of friction between the rock and the binder, the geometry of longitudinal section of the anchor bolt and its tensile strength.

Research method. The research was done by the analytical method using laws of the classical theory of elasticity and method of laboratory research.
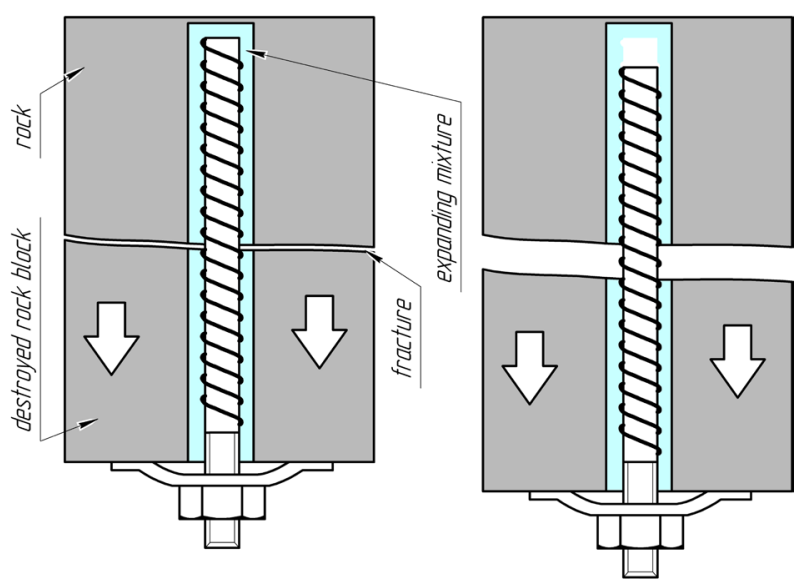

Fig. 3. Scheme of "bolt - expanding mixture - rock" system
The diagram of forces in the anchorage system with the fixation of bolt with the self-expansion mixture to the smooth steel bolt of the constant cross section is shown in Fig. 4.

For this case, the bearing capacity can be calculated by functional connection

$$
F=\min \left(F_{f t} ; F_{f r 1} ; F_{s m} ; F_{s t} ; F_{t b}\right),
$$

where $F_{f r}$ is the frictional force between the bolt and binder, $\mathrm{kN} ; F_{f r 1}$ is the frictional force between the binder and rock massive, $\mathrm{kN} ; F_{s m}$ is the shear force of the binder at the dangerous section, $\mathrm{kN} ; F_{t b}$ is the tensile strength of bolts, $\mathrm{kN}$.

$$
F_{f r}=P_{e m} \cdot \pi \cdot d_{b} \cdot l \cdot f_{f r}
$$

where $P_{e m}$ is the pressure caused by expanding binder mixture, $\mathrm{kPa} ; d_{b}$ is the bolt diameter, $\mathrm{m} ; l$ is the length of the bolt in rock massive, $\mathrm{m} ; f_{f r}$ is the coefficient of friction between the bolt and the self-expanding mixture.

$$
F_{f r 1}=P_{e m} \cdot \pi \cdot d_{b h} \cdot l_{1} \cdot f_{f r 1},
$$

where $d_{b h}$ is the hole diameter, $\mathrm{m}$; $l$ is the length of a hole with an self-expanding mixture in the rock massive, m; $f_{f r 1}$ is the frictional force between the binder and rock massive, $\mathrm{kN}$.

$$
F_{s m}=\tau_{s m} \cdot S_{s m}
$$

where $\tau_{s m}$ is the shear strength of self-expanding mixture $\mathrm{MPa} ; S_{s m}$ is the area of dangerous cross-section of the binder mixture, $\mathrm{m}^{2}$.

$$
F_{s r}=\tau_{s r} \cdot S_{s r}
$$

where $\tau_{s r}$ is the shear strength of rock, MPa; $S_{s m}$ is the area of dangerous cross-section of rock around borehole, $\mathrm{m}^{2}$.

The given formulas are obtained according to an idealized scheme. It does not consider the non-linearity of distribution of both normal and tangential stresses, strength properties of rock, binder and metal, moving the contact surface along the bolt in the process of yielding. Therefore, they can be considered as the first approximation to the calculation of bolt parameters.

Laboratory studies were conducted on a natural scale. The rocks were imitated by concrete poured into steel pipes with an internal diameter of $100 \mathrm{~mm}$ and a height of $200 \mathrm{~mm}$. The term of concrete hardening is

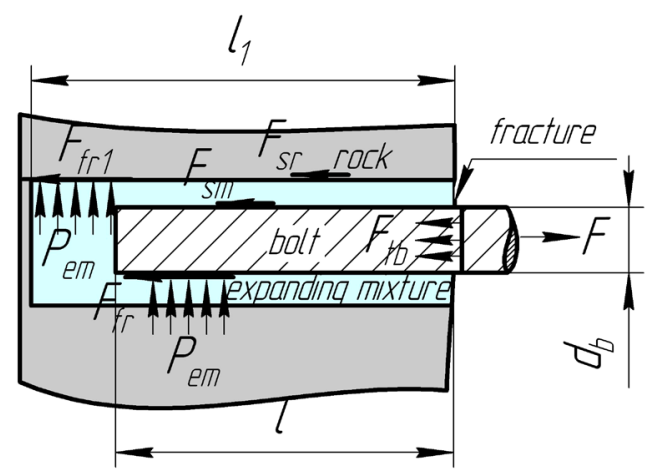

Fig. 4. Scheme of forces in the "bolt-expanding mixture - rock" system 
28 days. The strength of single-axial compression, established on the test results on concrete samples, was $34 \mathrm{MPa}$. The samples were formed by holes of 32 and $43 \mathrm{~mm}$ in diameter, which simulated the boreholes. Anchor bolts were modeled with reinforcement of 20 and $32 \mathrm{~mm}$ in diameter. Two series of tests were conducted:

- on samples with a ameter of boreholes of $32 \mathrm{~mm}$ and diameter of bolts of $20 \mathrm{~mm}$;

- on samples with a diameter of boreholes of $43 \mathrm{~mm}$ and diameter of bolts of $32 \mathrm{~mm}$.

The scheme of the experiment was as follows (Fig. 5). In the bottom part of boreholes on a thickness of $50 \mathrm{~mm}$, foam plastic was placed, after which a mixture was poured into the hole, which was expanding with hydration, and the anchor bolt was set. The bolt protruded above the sample by $100 \mathrm{~mm}$. After solidification, the samples were loaded on the press (Fig. 5). In this case, fixed axial load and deformation were recorded. The test was performed until the bolt was fully lowered by $50 \mathrm{~mm}$.

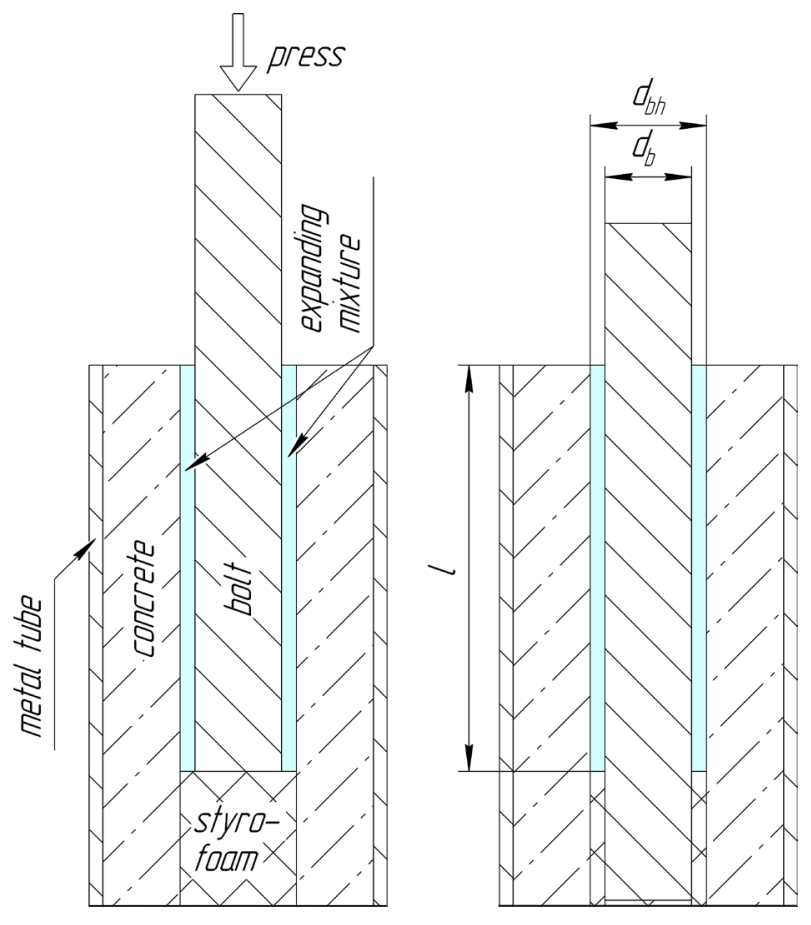

$a$

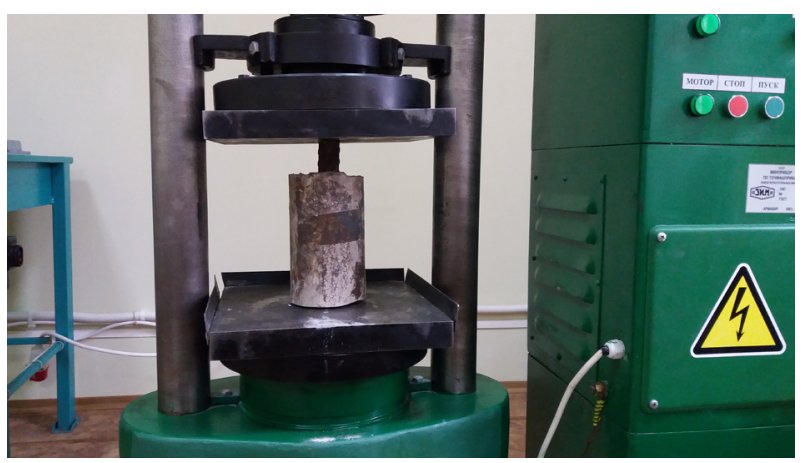

$b$

Fig. 5. Scheme of the laboratory experiment (a) and its general view (b)
This setting of a laboratory experiment is idealized. In-site bolt works on tensile, not compression, in the experiment conducted. In-situ the bolt is tensile, and at the same time its diameter decreases slightly. Therefore, the actual values of bearing capacity will be less than those obtained in the experiments, where the bolt becomes thicker when compressed. But in spite of this, it is obvious that the bearing capacity of the "bolt - expanding mixture - rock" system varies according to certain laws, which in the first approximation can be formulated on the basis of experiments.

Research results and their discussion. The pressure developing the fixing mixture during expansion in the process of hydration hardening depends mainly on the formulation of mixture, temperature of rocks and their deformation properties [10]. This shear strength of the fixing mixture is also a function of the parameters given. Investigation of properties of self-expanding mixtures allowed establishing the corresponding dependences of expansion pressure and their shear characteristics on the specified parameters [10].

Examples illustrating dependency analysis (1-5) for bolt diameter $d_{b}=20 \mathrm{~mm}$, borehole diameter $d_{b h}=$ $=32 \mathrm{~mm}$, a length of the borehole with expanding mixture, in rock massive $l=0.2 \mathrm{~m}$ are shown in Figs. 6, 7 .

The multivariable factor relations do not allow us to uniquely estimate the given dependencies for the entire range of conditions. But if we confines ourselves to rocks of medium strength and strong ones (with a strength of not less than fixing mixture) and bolts with diameters over18 mm made of steel and fiberglass, then the shear force of fixing mixture and the frictional forces between the bolt and the fixing mixture will be the most dangerous (the smallest) with other equal conditions. This is due to the smaller plane of the anchor surface than the hole.

At the expansion pressure of a fixing mixture being

$\mathbf{f}_{\mathrm{fr}}$

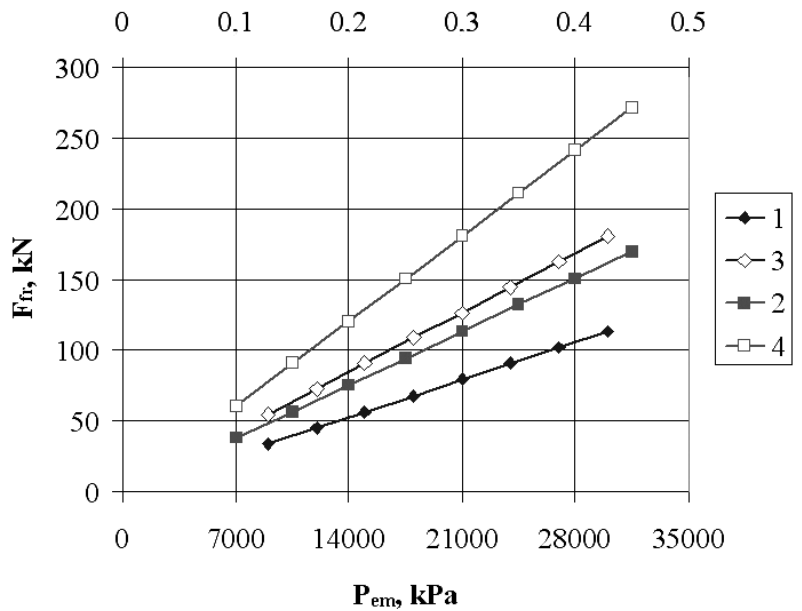

Fig. 6. Graphs of friction force between the bolt and the fixing mixture (curves 1, 2) and fixing mixture and rock (curves 3,4$)$ from the expansion pressure of fixing mixture (curves 1,3 ) with a coefficient of friction $=0.3$ and a coefficient of friction (curves 2, 4) with an expansion pressure $=30.000 \mathrm{kPa}$ 


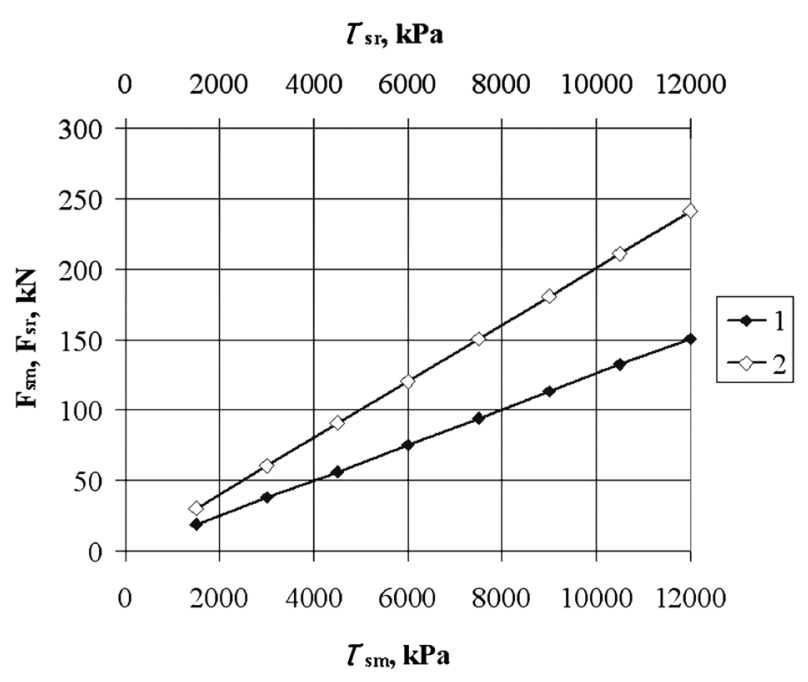

Fig. 7. Graphs of dependence of the shear force of fixing mixture and rocks on the strength of shear fixing mixture (curve 1) and rock (curve 2)

$30 \mathrm{MPa}$ and the coefficient of friction 0.3 the emerging forces are equal to the share forces of fixing mixture with a margin of strength of $9 \mathrm{MPa}$. For a bolt with a diameter of $20 \mathrm{~mm}$ and a length of $0.2 \mathrm{~m}$, the design value of the force is $113.04 \mathrm{kN}$.

Increasing the coefficient of friction between the mixture and the bolt, for example due to the use of a profile anchor bolt or increasing the pressure of expansion of fixing mixture, will not increase the bearing capacity of the bolt. This is because the strength of fixing mixture on the cut will not change, which will limit the carrying capacity of the "bolt - expanding mixture - rock massive" system to the smallest factor $F_{s m}$, according to (1). According to the above dependencies, it is obvious that an increase in the length of the working part of the bolt leads to a proportional increase in the bearing capacity of the system. In this, the fixing mechanism in the proposed method coincides with the known friction bolts Swellex, Omega, and others. Accordingly, the bearing capacity of $1.0 \mathrm{~m}$ in length will increase proportionally and make up $565.2 \mathrm{kN}$, which is not less than the known energy absorbing bolts.

Laboratory tests allowed checking the theoretical results obtained in practice. It is established that the mode of operation of anchors has two characteristic zones: ridding and yielding. In a ridding mode, the bolt works at relative deformations of about $0.95 \%$, after which the bolt is slid relative to the fixing mixture and its movement occurs with a roughly constant resistance (Fig. 8). The bearing capacity of the system in the ridding mode on the basis of the calculation results for an anchor diameter of $20 \mathrm{~mm}$ is $84.75 \mathrm{kN}$, according to the results of the tests it is $102 \mathrm{kN}$, for the bolt of $32 \mathrm{~mm}$ in diameter $135.6 \mathrm{kN}$ and $146 \mathrm{kN}$, respectively.

Deformations and loading obtained in laboratory conditions were due to the size and design of a physical model. The actual length of bolt fastening was $150 \mathrm{~mm}$, the maximum deformation was limited to $50 \mathrm{~mm}$. The bearing capacity in such a statement is

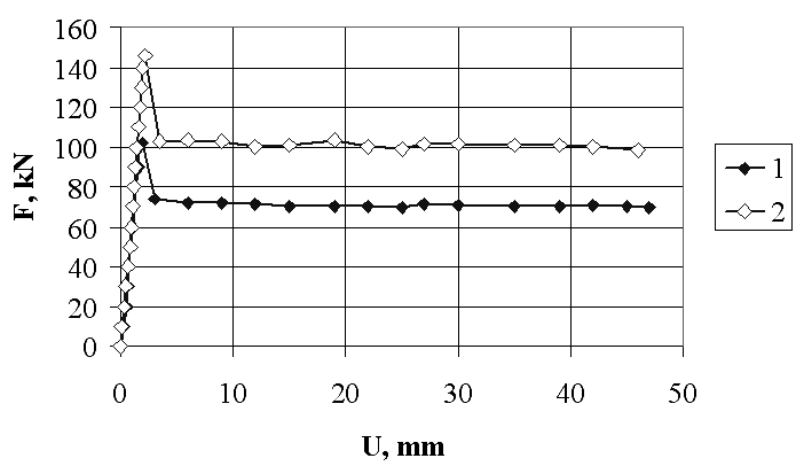

Fig. 8. Dependence diagrams "loading - deformation" while testing bolts fixed by self-expanding blends:

1 - the diameter of the bolt is $20 \mathrm{~mm}$, the diameter of a borehole is $32 \mathrm{~mm}$; 2 - the diameter of a bolt is $32 \mathrm{~mm}$, the diameter of a borehole is $43 \mathrm{~mm}$

linearly proportional to the length of the working part of the bolt.

In order to evaluate the efficiency of attachment of bolts to self-expanding blends, a control series of tests were conducted for the given experimental scheme. In these tests, fixing of bolts with a diameter of $20 \mathrm{~mm}$ in hollows with a diameter of $32 \mathrm{~mm}$ was carried out with fast-hardening mixtures: a bolt resin Cement KL (Orica) and a resin KF-MT-15 with anhydride fixing mixture in a proportion of $10: 1$. The results are presented in Fig. 9.

It has been established that adhesive-bonded bolts have a rigid mechanism of deformation. The load carrying capacity reaches the maximum load almost linearly, after which it decreases with the slow growth of deformations. Under these conditions, the maximum expansion effort of exhausting blends exceeds the strength of the bolts fixed by the resin by more than twice, and the forces of yielding are by $67 \%$ more than in the experiment with fixing Cement KL (Orica) and by $99 \%$ more than the resin KF-MT-15 Thus, the efficiency of the proposed solution has been experimentally proved.

Increase in the bearing capacity of an anchor system,

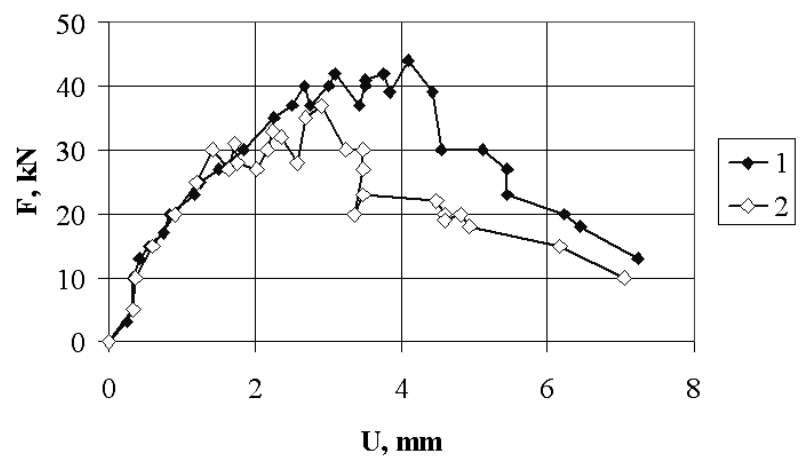

Fig. 9. Dependence diagrams of "loading - deformation" while testing bolts fixed by fast-hardening mixtures (the diameter of a bolt is $20 \mathrm{~mm}$, the diameter of a borehole $-32 \mathrm{~mm}$ )

1 - Cement KL (Orica); 2 - resin KF-MT-15 with anhydride fixing mixture 10:1 
when attached with expanding mixture, in a yielding mode can occur due to implementation of the bolt of the alternating section or the formation of local zones with a larger diameter of the bolt.

Conclusions and recommendations for further research. The efficiency of fixing anchor bolts with selfexpanding blends with hydration with a pressure of 30-50 MPa has been theoretically and experimentally proved. Analyzing the operating conditions of such bolts, it can be stated that the "bolt - fixing mixture rock massive" system has an operating mechanism similar to energy - absorbing bolts. In order to accurately estimate the energy of bolts fixed by the self-expanding mixtures and their adequate comparison with known structures, it is necessary to perform their parallel testing. The presented results are the initial step of the study. Further work will be aimed at improving the proposed solutions and their testing in mine conditions.

\section{References.}

1. Li, C. C., 2012. Performance of D-bolts Under Static Loading, Rock Mechanics and Rock Engineering, 45, pp. 183-192. DOI: 10.1007/s00603-011-0198-6.

2. Wen, Z.J., Qu, G.L., Wen, J.H., Shi, Y.K. and Jia, C.Y., 2014. Deformation failure characteristics of coal body and mining induced stress evolution law, The Scientific World Journal, 5, pp. 1-8.

3. Walentek, A. and Lubosik, Z., 2017. Optymalizacja obudowy wyrobisk przyścianowych zlokalizowanych na głębokości większej niż 1000 m. Przeglad Górniczy, 2, pp. $76-84$.

4. Chen, J., Hagan, P. C. and Saydam, S., 2016. Load transfer behavior of fully grouted cable bolts reinforced in weak rocks under tensile loading conditions. Geotechnical Testing Journal, 39(2), pp. 252-263. DOI: 10.1520/ GTJ20150096.

5. Wen, Z.J, Jiang, Yu.J., Han, Z. H., Yang, S. and Wang, X., 2016. Anchoring Principles of a New EnergyAbsorbing Expandable Rock Bolt, Engineering Transactions, 64(1), pp.89-103.

6. Li, C. C., Stjern, G. and Myrvang, A., 2014. A review on the performance of conventional and energy-absorbing rockbolts Journal of Rock Mechanics and Geotechnical Engineering, 6, pp. 315-327. DOI: 10.1016/j.jrmge.2013.12.008.

7. He, M., Gong, W., Wang, J. Qi, P., Tao, Zh., Du, Sh. and Peng, Y., 2014. Development of a novel energy-absorbing bolt with extraordinarily large elongation and constant resistance. International Journal of Rock Mechanics and Mining Sciences, 67, pp. 29-42. DOI: 10.1016/j.ijrmms.2014.01.007.

8. Liang, Y., He, M., Cao, C., Wang, S. and Ren, T., 2017. A mechanical model for conebolts, Computers \&Geosciences, 83, pp. 142-151. DOI: 10.1016/j.compgeo.2016.10.017.

9. Sakhno, S. V., Isayenkov, O.O., Lyashok, Ya. O. and Sakhno, I. G., 2017. MPK(2006) C04B 7/00 Self-expanding non-explosive mixture. Ukraine. Pat. 119161, 10. Sakhno, I. G. and Molodetsky, A. V., 2013. Laboratory studies of the dynamics of growth of self-expansion pressure of non-explosive destructive mixture in typical deformation modes, Ground control in mining, 20-21, pp. 3-17.

\section{Дослідження нового способу неадгезійного закріплення анкерів}

\section{I. Г. Сахно, С. В. Сахно}

Державний вищий навчальний заклад „Донецький національний технічний університет“, м. Покровськ, Україна, e-mail: ivan.sakhno@donntu.edu.ua

Мета. Теоретична та експериментальна оцінка механізму роботи, несучої здатності та предруйнівних деформацій анкерної системи з новим неадгезійним закріпленням болтів.

Методика. Дослідження проведено аналітичним методом, з використанням положень класичної теорії пружності, і методом фізичного моделювання. Лабораторні тести на аксіальне навантаження болтів проведені в натуральному масштабі на зразках $з$ бетону, залитого в металеві труби. Випробування пройшли три серії моделей: дві серії із закріпленням болтів сумішами, що саморозширюються, i одна серія з адгезійним закріпленням. Результати представлені у виглядів графіків „навантаження деформація".

Результати. Аналітично встановлено діапазон коливання несучої здатності системи „болт - суміш, що розширюється - порода“ при зміні основних факторів. Розрахункова несуча здатність згаданої системи не менше ніж у відомих енерго-абсорбуючих болтів. Експериментально визначено механізм роботи анкерів, закріплених сумішами, що саморозширюються. Крива „навантаження деформація“ має жорстку й піддатливу зони, що характерно для енерго-абсорбуючих болтів. Максимальне зусилля закріплення анкерів сумішами, що розширюються перевищує зусилля для болтів, закріплених смолами, більше ніж у два рази, а зусилля в піддатливому режимі на $67 \%$ більше ніж максимальні в експерименті із закріпленням Cement KL (Orica) і на $99 \%$ більше ніж смолою КФ-MT-15.

Наукова новизна. Розкрито механізм активного фрикційного закріплення анкерних болтів за рахунок стиснення сумішами, що розширюються у твердій фазі у процесі гідратаційного твердіння. Створена анкерна система має високу несучу здатність при великих предруйнівних деформаціях. Доведена ефективність закріплення анкерних болтів сумішами, що саморозширюються при гідратації 3 утворенням тиску 30-50 МПа.

Практична значимість. Використання результатів дослідження дозволяє підвищити ефективність підтримання гірничих виробок анкерними системами, підвищити стійкість порід при великих позамежних деформаціях.

Ключові слова: анкерний болт, несуча здатність анкера, деформації, суміш, що саморозширюється, енерго-абсорбуючий болт, закріплення анкера 


\section{Исследование нового способа неадгезионного закрепления анкеров}

\section{И. Г. Сахно, С. В. Сахно}

Государственное высшее учебное заведение „Донецкий национальный технический университет“, г. Покровск, Украина, e-mail: ivan.sakhno@donntu.edu.ua

Цель. Теоретическая и экспериментальная оценка механизма работы, несущей способности и предразрушающих деформаций анкерной системы с новым неадгезионным закреплением болтов.

Методика. Исследование проведено аналитическим методом, с использованием положений классической теории упругости, и методом физического моделирования. Лабораторные тесты на аксиальное нагружение болтов проведены в натуральном масштабе на образцах из бетона, залитого в металлические трубы. Испытания прошли три серии моделей: две серии с закреплением болтов саморасширяющимися смесями и одна серия с адгезионным закреплением. Результаты представлены в виде графиков „нагрузка - деформация“.

Результаты. Аналитически установлен диапазон колебания несущей способности системы „болт саморасширяющаяся смесь - порода“" при изменении основных факторов. Расчетная несущая способность данной системы не менее чем у известных энерго-абсорбирующих болтов. Экспериментально определен механизм работы анкеров, закрепленных саморасширяющимися смесями. Кривая „нагрузка - деформация“ имеет жесткую и податливую зоны, что характерно для энерго-абсорбирующих болтов. Максимальное усилие закрепления анкеров расширяющимися смесями превышает усилия для болтов, закрепленных смолами, больше чем в два раза, а усилия в податливом режиме на $67 \%$ больше чем максимальные в эксперименте с закреплением Cement KL (Orica) и на 99 \% больше чем смолой КФ-МТ-15.

Научная новизна. Раскрыт механизм активного фрикционного закрепления анкерных болтов за счет сжатия смесями, саморасширяющимися в твердой фазе в процессе гидратационного твердения. Создана анкерная система, которая обладает высокой несущей способностью при больших предразрушающих деформациях. Доказана эффективность закрепления анкерных болтов смесями, которые саморасширяются, при гидратации с образованием давления 30-50 МПа.

Практическая значимость. Использование результатов исследования позволяет повысить эффективность поддержания горных выработок анкерными системами, повысить устойчивость пород при больших запредельных деформациях.

Ключевые слова: анкерный болт, несущая способность анкера, деформации, саморасширяющаяся смесь, энерго-абсорбирующий болт, закрепление анкера

Рекомендовано до публікації докт. техн. наук С.В.Подкопаєвим. Дата надходження рукопису 06.11.17. 